\title{
Effect of hydro-alcoholic extract of yellow horned poppy (Glaucium flavum) on serum concentration of glucose and lipid profile and weight changes in alloxan induced diabetic rats
}

\author{
Darya GHH ${ }^{1}$, Nowroozi-Asl A ${ }^{2}$, Khoshvaghti A ${ }^{3}$, Rahmani Moghaddam E ${ }^{4}$, Musavi SM ${ }^{5}$ \\ 1. Doctor of Veterinary Medicine, Young Researchers and Elites Club, Islamic Azad University, Kazerun, Iran, \\ (Corresponding Author) Email: ghdarya88@gmail.com. \\ 2. Associate Professor of Veterinary Internal Medicine, Department of Clinical Science, Faculty of Veterinary Medicine, \\ Kazerun Branch, Islamic Azad University, Kazerun, Iran. \\ 3. Associate Professor of Clinical Pathology, Department of Clinical Science, Faculty of Veterinary Medicine, Kazerun \\ Branch, Islamic Azad University, Kazerun, Iran. \\ 4. MSc Student, Department of Anatomical Science, Student Research Committee, Shiraz University of Medical Science, \\ Shiraz, Iran. \\ 5. Doctor of Veterinary Medicine, Shahid Chamran University, Ahwaz, Iran.
}

\begin{abstract}
Background \& Aim: Yellow horned poppy is known as an antidiabetic drug in Iran folk medicine. This study was conducted to compare the effect of yellow horned poppy and glibenclamide on blood glucose concentration, blood lipid profile and weight of alloxan-induced diabetic rats.

Materials \& Methods: 40 male rats were randomly divided into five groups of eight: 1)healthy control 2)healthy treated with $500 \mathrm{mg} / \mathrm{kg}$ of body weight (BW)/day of the extract 3)diabetic control 4)diabetic treated with $500 \mathrm{mg} / \mathrm{kg}$ of BW/day of the extract 5)diabetic treated with $5 \mu \mathrm{g} / \mathrm{kg}$ of BW/day of glibenclamide. Diabetes induced in the $3^{\text {rd }}, 4^{\text {th }}$ and $5^{\text {th }}$ groups by intraperitoneal injection of 120 $\mathrm{mg} / \mathrm{kg} \mathrm{BW}$ of alloxan. The weight of rats was measured after 1, 14 and 28 days. After a month, animals were euthanized and blood samples collected to measure serum levels of fasting blood glucose, triglyceride, cholesterol and lipoproteins including: HLD-C and LDL-C by an auto-analyzer. Data analysis was performed by repeated measure Anova, one way Anova_and Tukey test.

Results: We found a significant decrease in glucose concentration in the diabetic+extract group compared to the diabetic control $(\mathrm{P}<0.001)$, this decrease_was significantly lower than that in the diabetic+drug group $(\mathrm{P}=0.03)$. Triglyceride, cholesterol and LDL concentrations in the diabetic+extract group showed a significant decrease compared to those in the diabetic control group $(\mathrm{P}<0.001)$. Significant increase in HDL concentration was observed in the diabetic+extract group compared to that in the diabetic control group $(\mathrm{P}<0.001)$.

Conclusion: The present study showed antidiabetic effect of yellow horned poppy in the rats which is comparable to the effect of glibenclamide.
\end{abstract}

Keywords: Diabetes mellitus, Glaucium flavum, FBS, Lipid profile, Rat, Alloxan

Recevied: Jan 10, 2019

Accepted: Jan 29, 2019

How to cite the article: Darya GHH, Nowroozi-Asl A, Khoshvaghti A, Rahmani Moghaddam E, Musavi SM. Effect of hydro-alcoholic extract of yellow horned poppy (Glaucium flavum) on serum concentration of glucose and lipid profile and weight changes in alloxan induced diabetic rats. SJKU 2019; 24 (1): 45-55.

Copyright (C) 2019 the Author (s). Published by Kurdistan University of Medical Sciences. This is an open access article distributed under the terms of the Creative Commons Attribution-Non Commercial License 4.0 (CCBYNC), where it is permissible to download, share, remix, transform, and buildup the work provided it is properly cited. The work cannot be used commercially without permission from the journal. 
تاثير عصار هء هيدروالكلى شقايق كوهى (Glaucium flavum) بر غلظت سرمى كلوكز و الكوى جربى

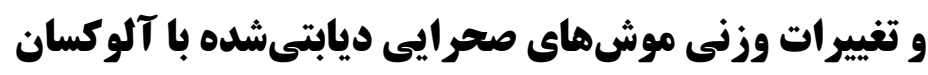

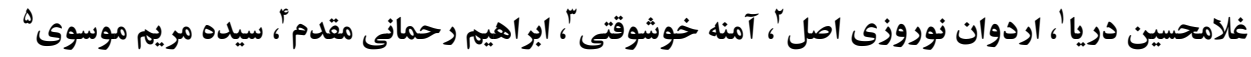

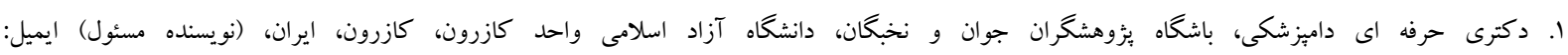
ghdarya88@gmail.com r. دانشيار بيمارى هاى داخلى داميزشكى، گروه علوم بالينى، دانشكده داميزشكى، دانشگاه آزاد اسلامى واحد كازرون، كازرون، ايران.

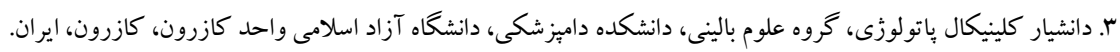

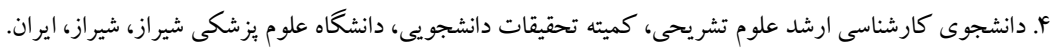
هـ دكترى حرفه اى داميز شكى، دانشكاه شهيد حِمر ان، اهواز، ايران.

جكکبه زمينه و هدف: گیاه شقايق كوهى در طب سنتى ايران براى كاهش عوارض ديابت استفاده مىشود. اين مطالعه براى مقايسه اثر

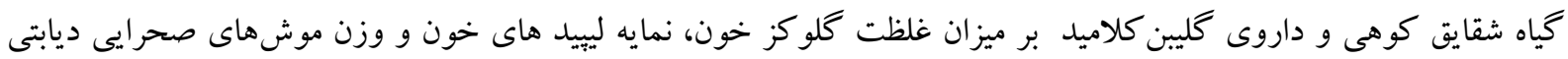
القاء شده با آلو كسان صورت بذيرفت. مواد و روشها: جهل سر موش صحر ايى نر به طور تصادفى به بنج گروه هشتايى تقسيم شدند: شاهد سالم، سالم تيمار با عصاره

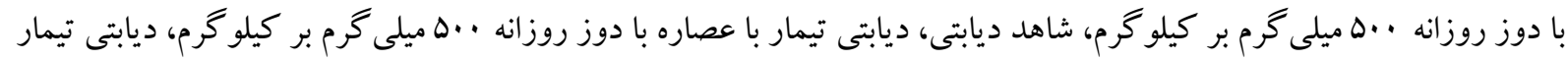

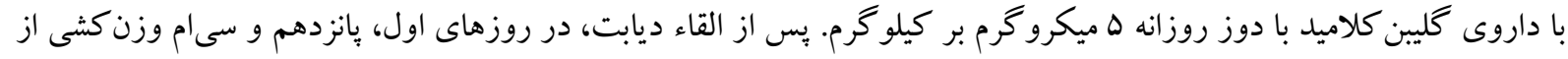

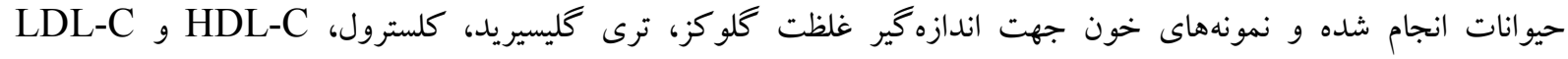

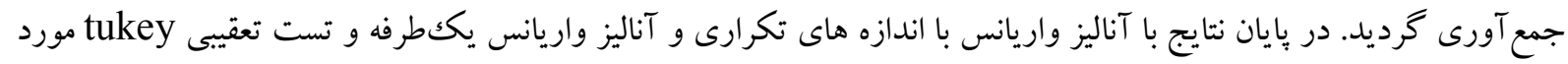
تحليل آمارى قرار گرفت.

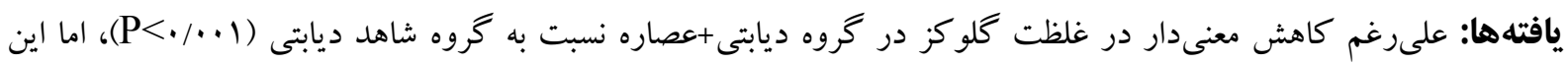

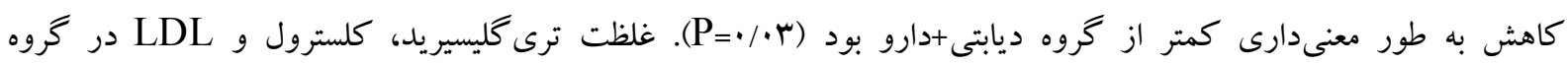

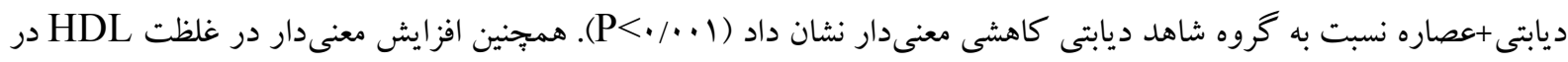

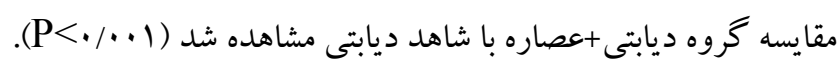

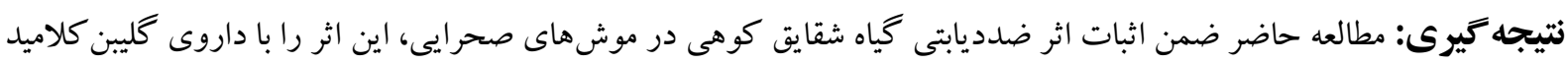
قابل قياس مى داند. وازه كان كليدى: ديابت، شقايق كوهى، كلو كزخون، الكوى جربى، موش صحر ايیى، آلو كسان

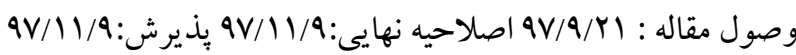


كونه شقايق كوهى (Glaucium flavum) كه به شقايق شاخدار زرد (Yellow Horne Puppy) و يا كلاتين (نام بومى و معروف در ميان افراد محلى در كازرون و برخى

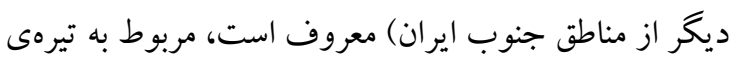

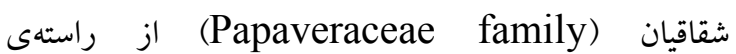
آلالهسانان مىباشد (F). بخشهاى وسيعى از غرب و جنوب غربى ايران نيز علاوه بر كوهستانى بودن جز مناطق

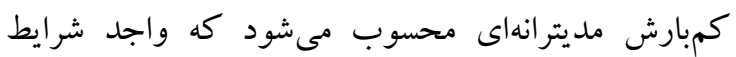

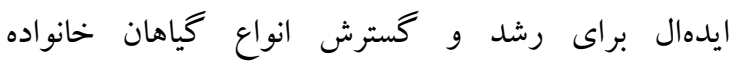
شقايقسانان و از جمله اين گُنه است (ه). اين خياه سرشار از تركيبات آلكالوئيدى همجيون آيورفين(Aporphine)، بروتويين (Protopine)ويروتوبربرين (Protoberberine)

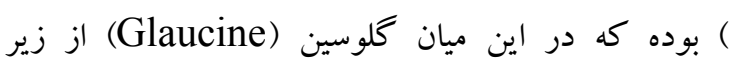

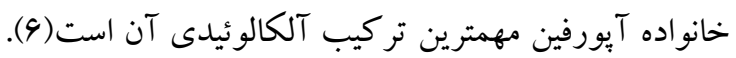

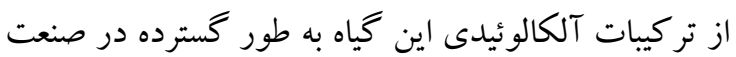
داروسازى به عنوان مسكن، ضد احتقان و ضد سرفه بهره بردارى مى شود(V).. تحقيقات اخير نيز خواص آنتىاكسيدانى، ضد سرطانى و ضد ويروسى را به كاربردهاى

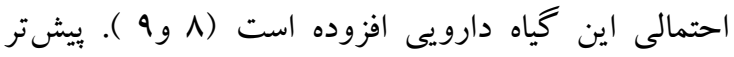

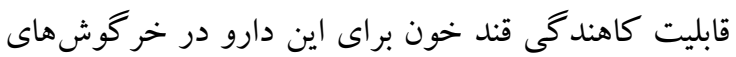

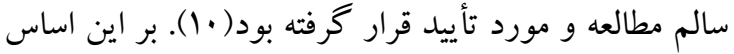
مطالعه حاضر جهت تعيين خواص ضدديابتى و خواص كاهنده فاكتورهاى ليييدى عصاره هيدروالكى شقايق كوهى در موشهاى صحرايى نر بالغ مبتلا به ديابت القايى توسط دوز •rا ميلى گرم بر كيلو گرم وزن بدن از آلو كسان، در

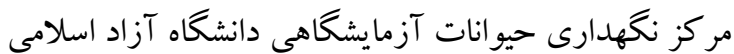

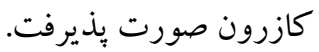

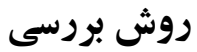 ا.جمع آورى كياه}

نمونهاى كياه شقايق كوهى در اوايل فصل بهاه از از مراتع

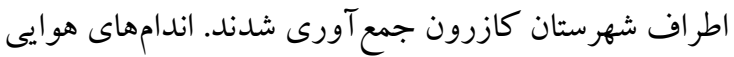
و گل هاى گياه بعد از خشك شدن در مجاورت تابش نور

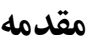

ديابت مليتوس به گروهى از بيمارى ها كفته مىشود، كه غلظت بالاى قند خون در نتيجهى نارسايى در ترشح

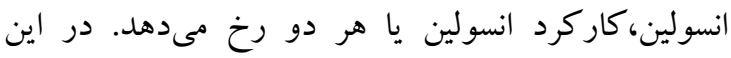

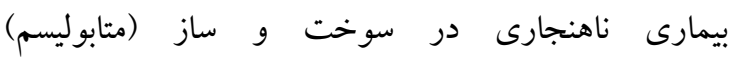
كربوهيدرات، بروتئين و جربى، نيز وجود دارد. بدن افراد

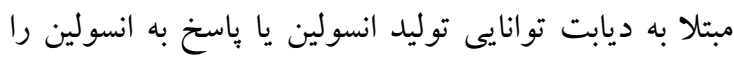
ندارد. حضور انسولين براى استفاده يا ذخيره سوختهاى

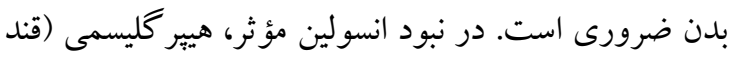

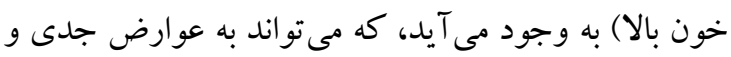

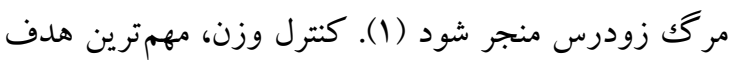

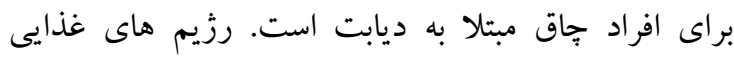
يركربوهيدرات، برفيبر و با جربى حيوانى كم، در كنترل قند

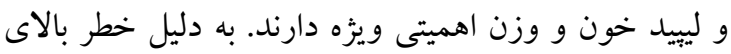
ابتلا به بيمارى قلبى -عروقى(CVD) (Cardiovascular ) Disease)، افراد ديابتى بايد يك ريك رويهء (استراتزى) ييشخيرانه براى طبيعى كردن لييدهاى سرم و به حداقل

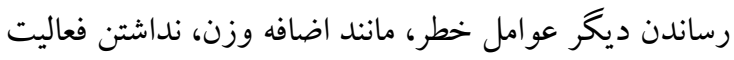
بدنى، برفشارى خون و استرس اكسيداتيو در بيش گيرند

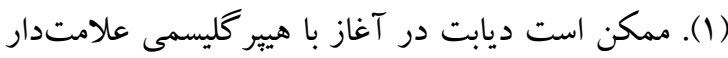
يا يك عارضهء ناشى از هيبر كليسمى شديد، كتواسيدوز يا

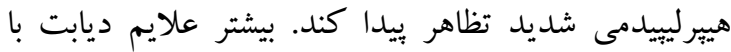

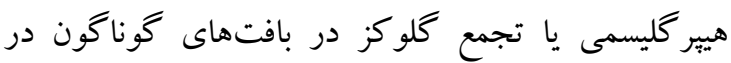

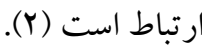
كَاهان دارويى و مشتقات آنها اكر جهاط از دير باز دردرمان ديابت قندى وعوارض ناشى از آن مطرح بوده اند، ولى در مورد اثر بخشى قطعى بسيارى از انها تا كنون شواهد تحقيقاتى و معتبر يافت نشده است(r). در طى •اتا •r سال

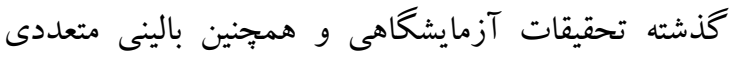
روى گياهان دارويى مورد استفاده در درمان ديابت انجام كرفته كه در تعدادى از آنها اثرات قابل ملاحظه اى در كاهش قند خون بيماران ديابتى مشاهده شده است . 
محدوديت غذايى اعمال گرديد (Y)). بعد از گذشتن سه روز از تزريق آلو كسان، درحالت ناشتا با كمكك دستخاه اندازه گيرى قند(كره جنوبى، Easygluco) قند خون را

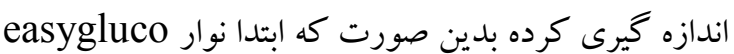

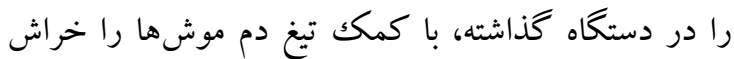
داده و يكك قطره از خون موش را روى نوار قرار داده و

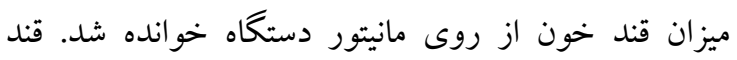

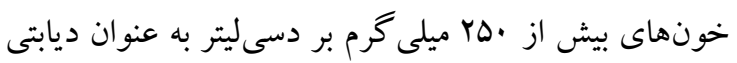

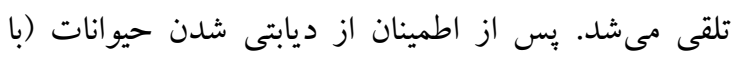

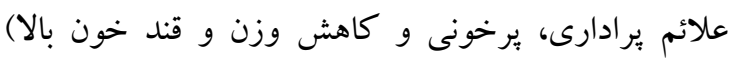
مصرف عصاره آبى - الكلى شقايق كوهى آغاز شد.

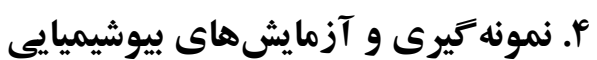
وزن كشى: جهت بررسى تاثير احتمالى عصاره گياه شقايق يقوني

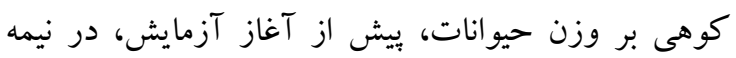
دوره (روز يانزدهم) و بيش از بايان دوره (روز سىام) همه به موشها توزين شده و مشخصات وزنى آنها يادداشت كرديد. خون كيرى: در بايان، حيوانات به كمك ماده بيهوش كننده اتر (ساخت شركت كيميا مواد، ايران) بيهوش شده و سبس به كمكك سرنگك هـ سى سى خون گيرى از ناحيه بطن راست قلب صورت گرفت. خون گرفته شده جهت تهيه سرم را در دستگاه سانتريفيوز (مدل Sigma301 10 آ اخت آلمان) با دور loborzentrifugen gmb به مدت ها دقيقه سانتريفيوز گرديد و سرم آن به وسيله

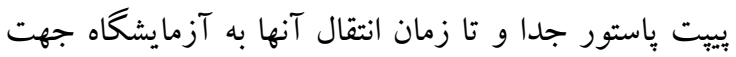
سنجش فاكتو رهاى مورد نظر در دماى •r- درجه سانتيخراد نغهارى شد. كلو كز بِلاسما به روش كلو كز اكسيداز (روش آنزيماتيك)، كلسترول بِلاسما به روش كلسترول اكسيداز (آنزيماتيك)، ترى گليسيريد به روش آنزيماتيك (آنزيم تيراكسيداز) ندازه كيرى شد.
در آسياب برقى يودر گرديده و جهت تهيه عصاره به

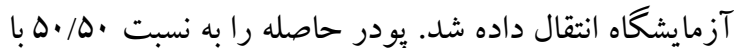
آب و الكل اتانول 99 درصد و به مدت VY ساعت خيسانده و سِّ آن راصاف نموده و در مر حله آخر در آون با دماى

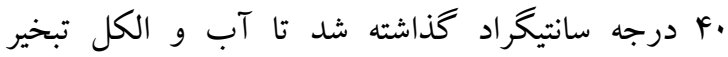
گرديده و يك شيره قهوه اى غليظ باقى ماند. از ..... أخرم

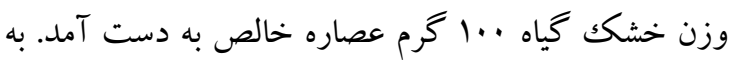
منظور تهيه سوسيانسيون خوراكى عصاره حاصل با سرم

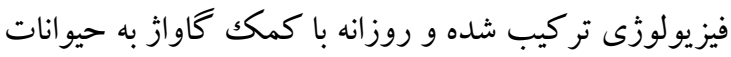

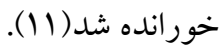
r. تروه بندى حيوانات

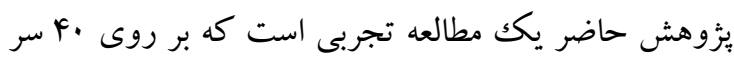

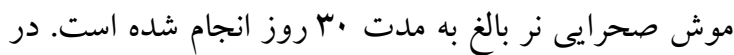

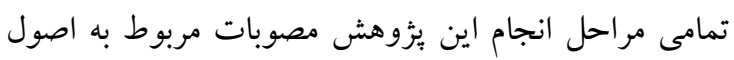

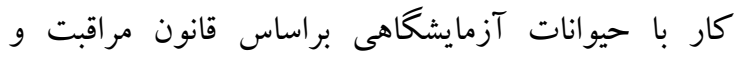

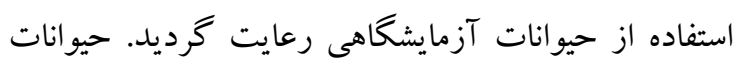
مورد استفاده در اين بُزوهش ابتدا وزن شده و در خزانه

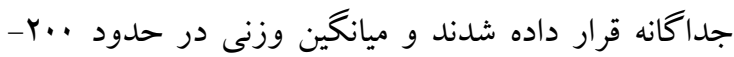

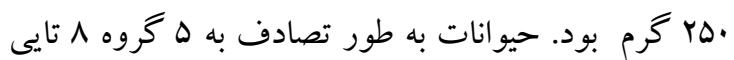

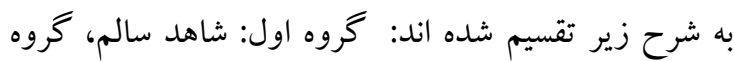
دوم: سالم تيماره شده با عصاره خوراكى شقايق كوهى با ناه

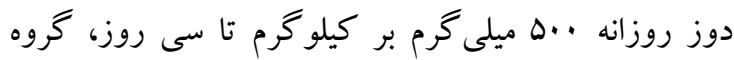
سوم: شاهد ديابتى، گروه جهارم: ديابتى درمان شده بانه

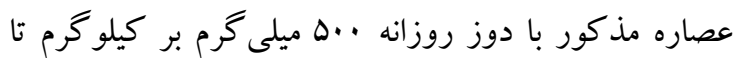

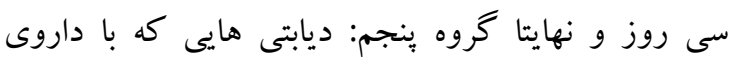

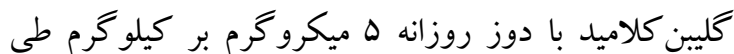
مدت مشابه تحت درمان قرار گر فتند. r. إ. روش القاى ديابت تجربى براى ديابتى كردن موشهاى صحرايى قبل از انجام آزمايش، از تزريق داخل صفاقى آلوكسان منوهيدرات

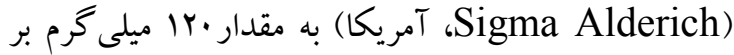
كيلو گرم استفاده گرديد. لازم به ذكر است كه به منظور افزايش اثر كذارى در القأ ديابت يكك دوره هشت ساعته 
كزارش كرديد. همجينين ه•/P> به عنوان ملاكك معنى بودن اختلاف بين گرووها در نظر كر فته شد.

نتايج نتايج حاصل از تغييرات قند خون: در مقايسه با گروه شاهد سالم، گروههاى شاهد ديابتى، ديابتى تيمار با عصاره و ديابتى تيمار با دارو افزايش معنىدارى را در سطح نشان داند. درمقايسه گروه سالم تيمار با عصاره نيز هر سه گروه شاهد ديابتى، ديابتى تيمار با عصاره و ديابتى تيمار با دارو افزايش معنىدارى در سطح (1) (P> (1) داشتند. از سويى تفاوت گروه شاهد ديابتى با تمام گرووهاى

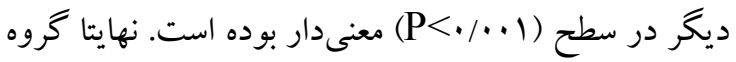
ديابتى تيمار با دارو كاهش معنىدارترى نسبت به گروه ديابتى تيمار با عصاره نشان شد (r=/ P= (جدول (1).
اندازه گيرى LDL-C با استفاده از فرمول فريدوال و HDL-C

محاسبه شدند( (1) ). اندازه گيرى ها همكى با كيت ها استاندارد (شركت يارس آزمون، ايران) و با كمكك دستگاه اتو آنالايزر تمام اتوماتيك ليك صورت بذيرفت. (Technicon RA-1000)

9. آناليز آمارى تعيين روابط معنىدارى براى تغييرات وزن با بهرهگيرى از آزمون Repeated measure و فاكتورهاى قند خون، ترى كليسيريد، كلسترول، LDL-C و TDL-C از آزمون آنووا و تست تعقيب tukey همخى در نرم افزار و يرايش ·rSPS مقادير به دست آمده به صورت (ميانگين \pm انحراف معيار)

جدول ا: مقايسه تغييرات قند خون (ميانگين \pm انحر اف معيار) در ميان ه گروه (n=^)

\begin{tabular}{|c|c|c|c|c|c|}
\hline \multicolumn{5}{|c|}{ F } & \multirow[b]{2}{*}{ فـــــاكــــــــور } \\
\hline ديابتى تيمار با دارو & ديابتى تيمار با عصاره & شاهد ديابتى & سالم تيمار با & شاهد سالم & \\
\hline$I V \Lambda / \Delta \pm \Delta / V \Delta$ & $19 \Delta / M \Lambda \pm \Delta / 9 \Lambda$ & $F G V / V D \pm 11 / r r$ & $1 \cdot \Delta / \Lambda \Lambda \pm r / 19$ & $\mid r \cdot / V \Delta \pm q / 4 A$ & قند خون mg/dl (FBS \\
\hline$a * b * c * d$ & $a * b * c *$ & $a * b *$ & & & \\
\hline
\end{tabular}

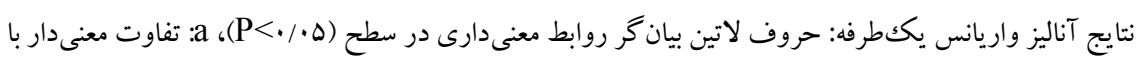

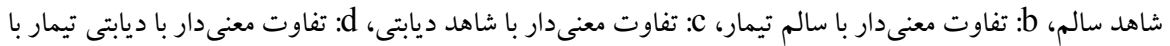

$$
\text { عصاره،علامت }
$$

ميانگينهاى كمتر از گروه ديابتى تيمار با دارو داشت

$$
\text { ( }(\mathrm{Y}=\cdot / \cdot)()
$$

در بررسى تغييرات كلسترول، گروه شاهد سالم قاقد تفاوت معنى دار با گروه هاى سالم تيمار با عصاره و ديابتى تيمار با

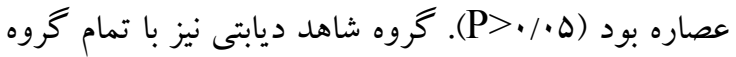

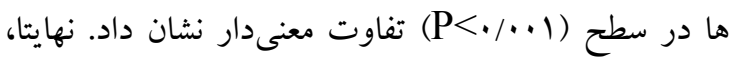
اعداد بدست آمده براى گروه ديابتى تيمار با عصاره به طور
نتايج مربوط به تغييرات غلظت ليييدها و لييو يروتئين هاى خون ميانگين غلظت ترى گليسيريد در گروه شاهد سالم به طور معنى (P=•/rA)

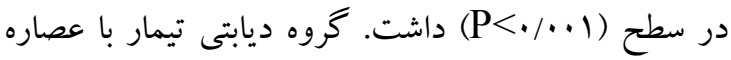
فاقد تفاوت معنىدار با گروه شاهد سالم بود (ه> (P> (ه) همجنين كروه ديابتى تيمار با عصاره به طور معنىدارى 
ميانخين سطوح سرمى LDL در گروه سالم تيمار با عصاره به طور معنىدارى كمتر از گروه شاهد سالم بوده است

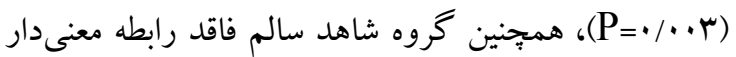

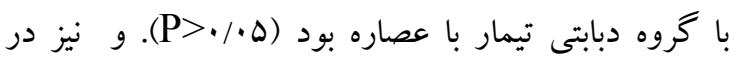

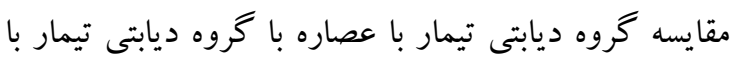

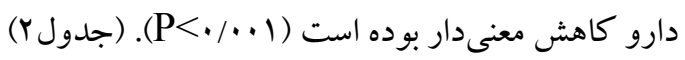

معنىدارى كمتر از گروه ديابتى تيمار با دارو بود

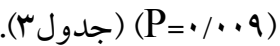
ميانخين غلظت HDL سرمى در گروه شاهد سالم به طور معنىدارى بيشتر از گروه سالم تيمار با عصاره بود

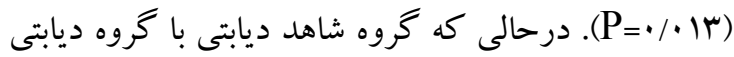

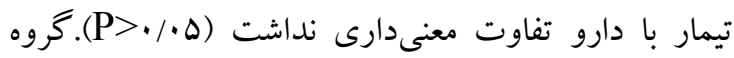

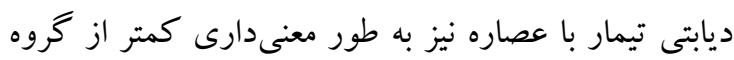

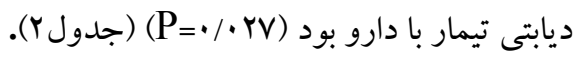

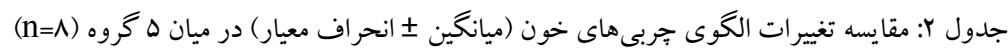

\begin{tabular}{|c|c|c|c|c|c|}
\hline \multicolumn{5}{|c|}{ F } & \multirow{2}{*}{ فاكتورهاى } \\
\hline ديابتى تيمار با دارو & ديابتى تيمار با عصاره & شاهد ديابتى & سالم تيمار با عصاره & 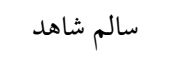 & \\
\hline \multirow{2}{*}{ 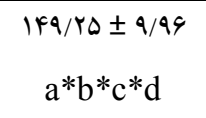 } & $Q Y / \Delta \cdot \pm \Lambda / F \Delta$ & $r H \Delta / 9 Y \pm \mid r / A r$ & $\Delta N / G Y \pm F / \cdot \Delta$ & $V G / G r \pm r / r \Delta$ & \multirow{2}{*}{ TG } \\
\hline & $\mathrm{c}^{*}$ & $a^{*} b^{*}$ & & & \\
\hline \multirow{2}{*}{$\begin{array}{l}q \vee / r V \pm r / q \Lambda \\
a * b * c * d\end{array}$} & $V Y / M Y \pm r / . q$ & $1 \Delta \Delta / A V \pm V / 19$ & $\Delta 1 / \cdots \pm r / 9 \Delta$ & $q \cdot / \Delta \cdot \pm r / r q$ & \multirow{2}{*}{ Chol } \\
\hline & $b c^{*}$ & $a * b^{*}$ & & & \\
\hline \multirow{2}{*}{$\begin{array}{c}r \cdot / r \pm 1 / 4 r \\
b * d\end{array}$} & $r \Delta / v \Delta \pm 1 / \Gamma r$ & IV/D. $\pm \cdot / \wedge 9$ & $r q / V \Delta \pm 1 / \Delta 9$ & $r \cdot 19 Y \pm \cdot / 99$ & \multirow{2}{*}{ HDL } \\
\hline & $\mathrm{c}^{*}$ & $a^{*} b^{*}$ & $\mathrm{a}$ & & \\
\hline \multirow{2}{*}{$\begin{array}{l}r q / r v \pm r / r q \\
a * b * c * d *\end{array}$} & $r 9 / \Delta \cdot \pm 1 / \pi r$ & $11 / 9 r \pm r / . q$ & $19 / \% \Delta \pm 1 / 94$ & $\Gamma \mid / N V \pm 1 / \wedge \varphi$ & \multirow{2}{*}{ LDL } \\
\hline & $\mathrm{bc}^{*}$ & $a * b *$ & $\mathrm{a}$ & & \\
\hline \multicolumn{6}{|c|}{ 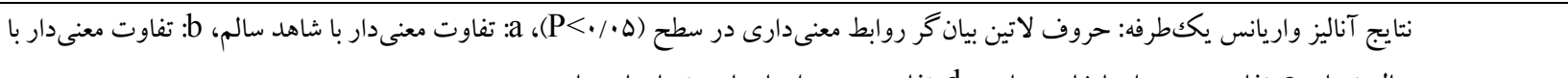 } \\
\hline & & ديابتى تيمار با عصارة & 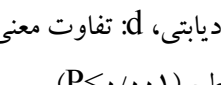 & 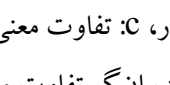 & \\
\hline
\end{tabular}

يانزدهم و سى ام كاهش مشاهده شده به صورت معنىدار بود

$$
\text { (جدول r) (P<•/.・1) }
$$

از منظرى ديخر با مقايسه تمامى گروهها درو روز روز سىام، نشان

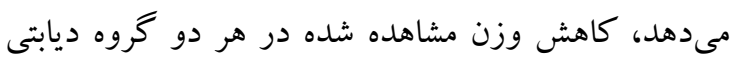

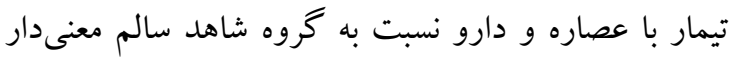

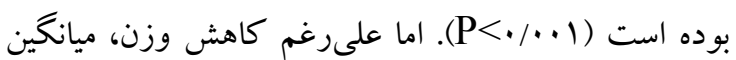
بدست آمده از گروه ديابتى تيمار با عصاره همجنان به طور

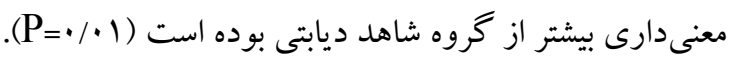

نتايج تغييرات وزن در سه مرتبه وزن كشى در گروه سالم تيمار با عصاره حاكى از كاهش معنىدار وزن در روزهاى لتعير

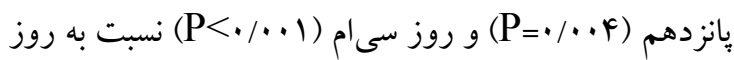

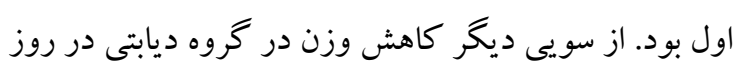

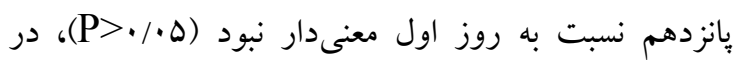

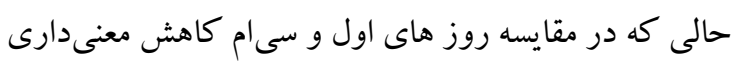

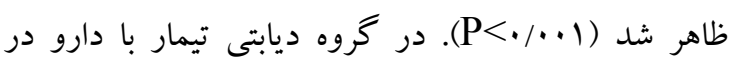
مقايسه روزهاى اول و هانزدهم كاهش معنىدار بود همجينين در مقايسه روزهاى اول و سى وام و نيز 


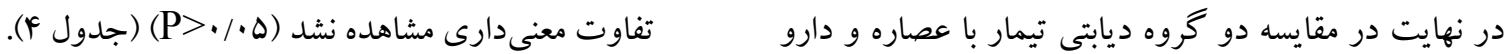

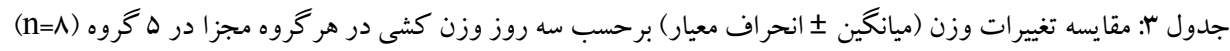

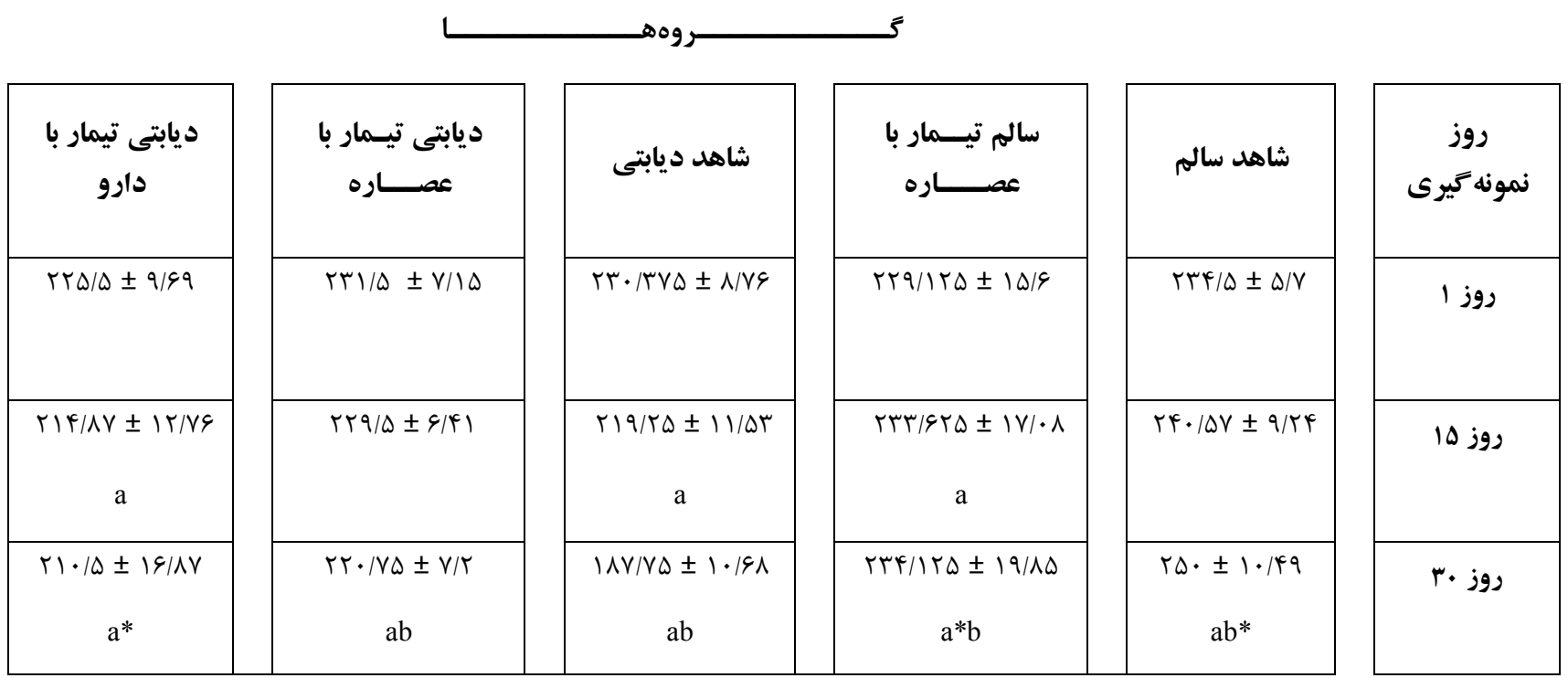

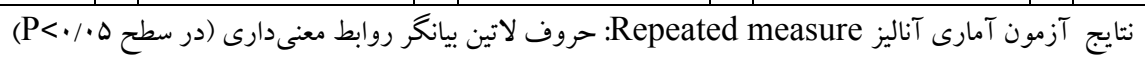

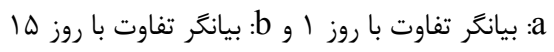

علامت

جدول f: مقايسه تغييرات وزن (ميانخين 土ـ انحر اف معيار) در ميان تمام گروهها در هر روز وزن كشى در ه گروه (n)

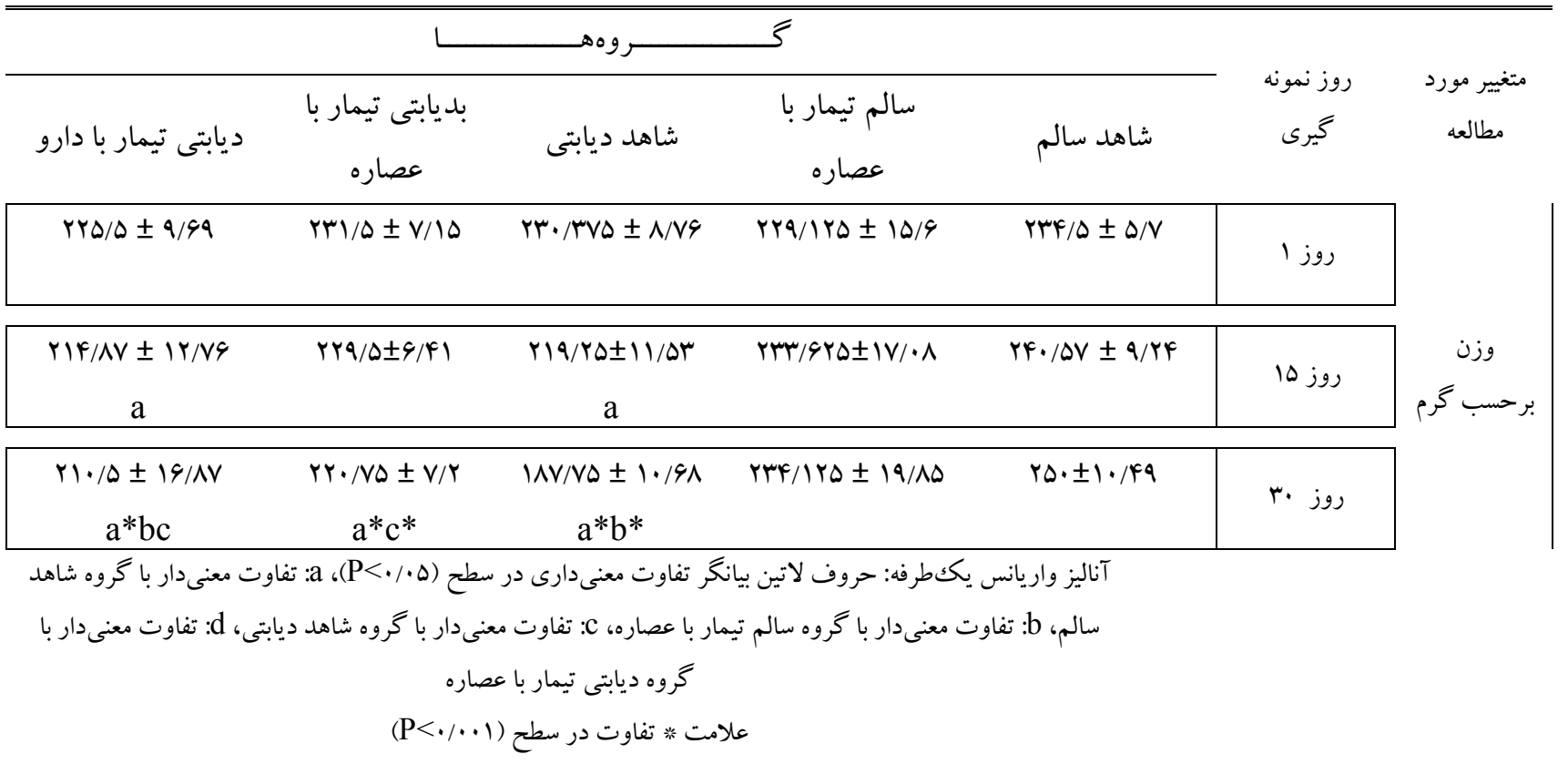


اين امر موجب احساس سيرى شده و در نهايت به كنترل وزن كمكك مى كند. مطالعات نيز افزايش وزن به دنبال مصرف فيبر در رزيم غذايى را ثابت مى كند(19). اما نكته قابل تامل در اين آزمايش مشاهده تاثير معنى دار عصاره

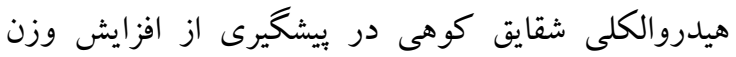

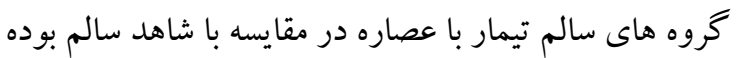

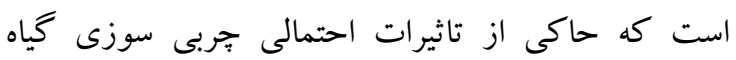
شقايق كوهى مى باشد.

\section{بررسى تاثير عصاره آبى-الكلى شقايق كوهى بر}

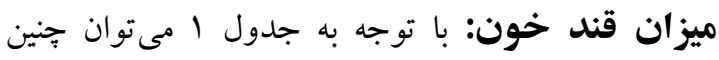
برداشت كرد كه آلو كسان عامل تخريب سلول هاى بتاى به لوزالمعده و درنتيجه كاهش توليد انسولين و ايجاد ديابت

$$
\text { در حيو انات مورد مطالعه است(IV). }
$$

گروه ديابتى تيمار با عصاره در مقايسه با گروه شاهد ديات ديابتى غلظت كلو كز كاهش معنىدارى را نشان داده است كه اين امر بيانكر آن است كه گياه شقايق كوهى داهي داراى خاصيت هييو گليسمى است. مطالعات ديخر بيان داشتهاند كه

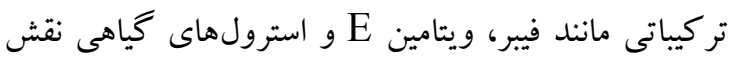
مهمى در تنظيم قند خون ايفا مى كنند كه حضور اين مواد در گياه مورد مطالعه دور از انظظار نمىباشد (ماو 19). اما

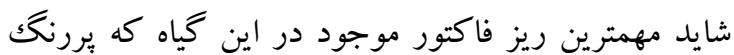
ترين و قابل توجه ترين تاثير را در كاهش قند خون دارد، آلكالوئيد هاى متعدد و متنوع موجود در آن باشد(·ب). مطالعات نشان داده است مصرف فيبر غلظت كلو كز بِاسما و مقدار كلو كز موجود در ادرار را كاهش مى دهد. همجنين جذب در روده كوجّك را كند كرده كه احتملا اين رويداد سبب تاخير در بازجذب كربوهيدرات ها شده و در نتيجه ميزان قند خون كنترل مى شود( اYY). مطالعات نشان داده كه كربوهيدرات هاى رزيم غذايى نقش مهمى در هموستاز كلوكز بازى مى كنند بنابر اين كربوهيدرات هاى موجود در شقايق كوهى با كاهش سرعت عبور مواد از لوله گوارش و جذب مواد تاثير كذاشته و كاهش غلظت كلوكز خون موجب كاهش نياز به انسولين مى گردد (YY). از طرفى
ديابت مليتوس يكى از مشكلات شايع يزشكى در تمام كشورها مى باشد. طبق گزارش انجمن ديابت ايران بيش از A درصد جمعيت كشور مبتلا به ديابت بوده و آمار مبتلا يان به اين بيمارى در ايران بيش از سه ميليون نفر مى باشد(rا). هرجند كه در حال حاضر درمان اصلى و موثر براى ديابت

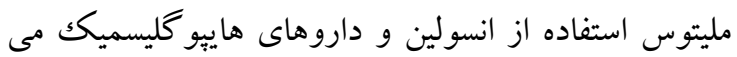

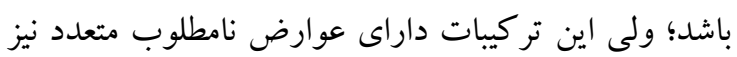
مى باشند(F). امروزه با توجه به اثرات جات جانبى داروهاى شيميايى مطالعه بر روى گياهان مورد استفاده در طب سنتى باته با هدف رسيدن به داروهاى جديد در اولويت قرار دارد.

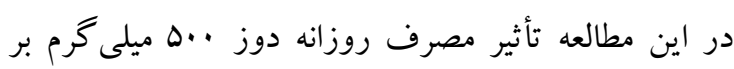
كيلو گرم بر حسب وزن بدن از عصاره آبى_الكلى گياه

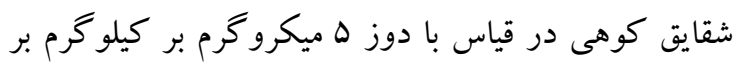
حسب وزن بدن از داروى زنريك كليبن كلاميد بر تغييرات وزن و سطوح سرمى قند خون ناشتا (FBS)، لييدهاى (C)

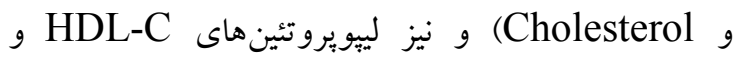
در موشهاى نر ديابتى شده با آلو كسان در بازهء يكك ماهه مورد ارزيابى قرار گرفت.

\section{بررسى تاثير عصاره آبى_الكلى شقايق كوهى بر}

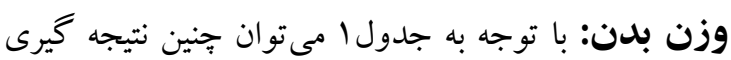
كرد كه القاى ديابت توسط آلو كسان موجب كاهش وزن بدن حيوانات مى شود، كه اين يافته با توجه به آنكه يكى از علائم ديابت كاهش وزن على رغم اشتهاى مناسب است، قابل انتظار مى باشد(ها). در گروههاى بيمار دريافت كننده عصاره تا حدودى افزايش وزن نسبت به شاهد بيمار ديده مى شود كه معنى دار نيز بوده است اما مانع كاملى جهت جلو گيرى از كاهش وزن و حفظ آن تا حد گروه هاى داى سالم نبوده است. كه احتمالا فيبر موجود در شقايق كوهى عامل اين افزايش بوده است. مطالعات نشان داده است فيبر موجود در مواد غذايى موجب كاهش يا به تاخير انداختن خروج

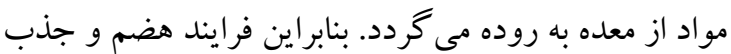

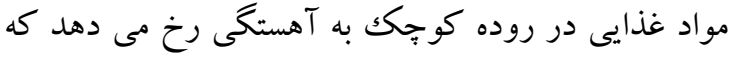


اتصال به كلسترول و فسفولييد را داشته و از جذب آنها جلو گيرى مى كنند(YV)... كانداليا و همكاران در سال در مطالعات خود روى افراد ديابتى به اين نتيجه رسيدند كه مصرف فيبر مقدار كلسترول تان، ترى كليسيريد و - مDL Kong و همكارانش در مطالعه اى C C كه با مصرف بربرين در بيماران ديابتى همراه بود كاهش قابل توجهى را در غلظت گَونه هاى مختلف جربى و لييو

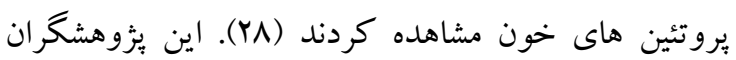

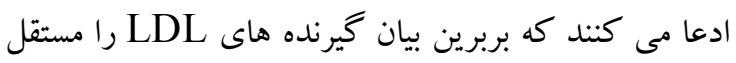
از ديخر شاخصهاى بروتئينى استرولها و با مكانيسم فعال

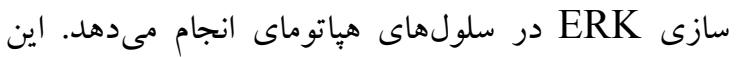
توضيح مىتواند كاهش قابل توجه جربىهاى مضر خون را

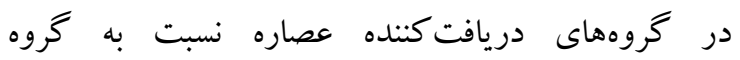
دريافت كننده دارو را در آزمايش حاضر تاييد كند.

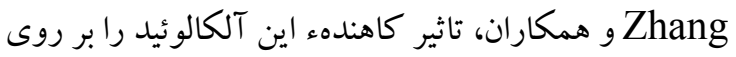
ترى گليسيريد خون بيشتر از انواع كلسترولها مىدانند (Y) (Y). كلوسين آلكالوئيدى است كه خاصيت آنتى اكسيدانى آن به به به اثبات رسيده است و مى تو اند اسيدهاى جرب باند مضاعف را در برابر يراكسيداسيون با واسطه راديكال آزاد محافظت كند (·r). تجويز اين آنتى اكسيدان از يراكسيداسيون برن ليييدها و لييويروتئينها جلو گيرى نموده و در نتيجه منجر به كاهش غلظت سرمى آنها مى گردد.

\section{نتيجه كيرى}

جمع بندى نتايج بدست آمده از اين مطالعه نشان مىدهد كه در ميان تمام فاكتورها، قند خون تنها موردى بود كه بهاي نتايجش حاكى از برترى داروى كليبن كلاميد نسبت به عصاره خوراكى كياه شقايق كوهى در دوز مورد مطالعه بوده است. اختلاف معنىدار گروه تيمار با عصاره با ديخر كروه هاى ديابتى اعم از شاهد و تيمار با دارو در مورد فاكتورهاى TG، كلسترول، HDL و LDL نشان دهنده برترى مطلق عصاره مورد مطالعه در مقايسه با داروى

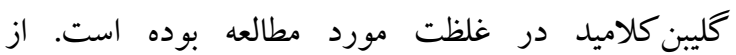

ديخر، خاصيت ضد التهابى آلكالوئيدها مى تواند يك دليل مهم در كاهش شدت علايم ناشى از غلظت بالاى كلوكز

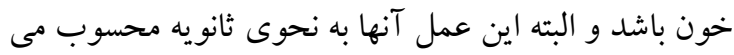
شود؛ از سويى آلكالوئيد كلوسين قادر است بان با اثرات التهابى و سمى آلو كسان به صورت اوليه مقابله كند و باعث

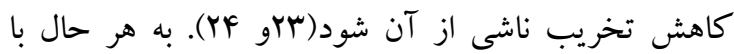
وجود مكانيسم هاى متعدد ذكر شده، داروى كليبن كلاميد عملكرد بهترى نشان داده است. فر آيندى كه اين دارو از آن بهره مى گيرد بستن كانال هاى K-ATP ديلاريزان غشا و و

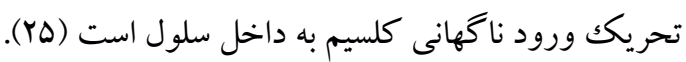
بررسى تاثير عصاره آبى-الكلى شقايق كوهى بر ميزان جربى خون: آنخونه كه انتظار مى رفت در مطالعه لئه

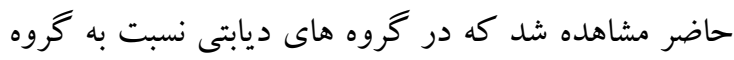
شاهد ميانگين مقادير كلسترول، LDL-C و ترى كليسيريد

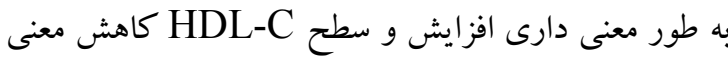
دارى نشان مى داد. در واقع القاى ديابت توسط آلو كسان با لقان تغيير لييويروتئين هاى بِلاسما و افزايش اكسيداسيون آنها و تغيير در تركيب اسيد هاى جرب و دانسيته لييويروتئين هاى

يلاسما همر اه است (Y4). از آنجا كه در برخى گروه هاى دريافت كننده عصاره سطوح سرمى ليييد ها نسبت به خروه شاهد ديابتى كاهش لرش يافته است بنابر اين شقايق كوهى داراى خاصيت هييوليييدمى مىباشد. مشاهده اين نتايج در مقايسه ميان دو گروه سالم تيمار با عصاره با خروه شاهد سالم نيز اين مسئله را تاييد مى كند. علت كاهش مشاهده شده در غلظتهاى مربوط به ليييدها و نيز لييويروتئينهاى مضر را مىتوان در حضور فيبر و آلكالوئيدهاى گياهى در عصاره مورد نظر جستجو كردو و

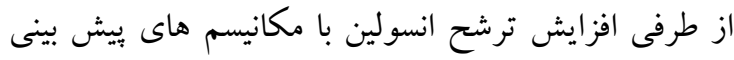

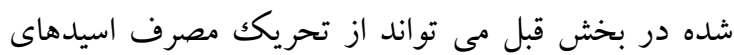

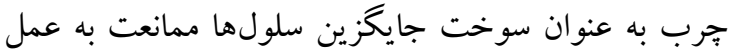
بياورد. در تحقيقاتى كه بر روى موش هاى صحرايى و

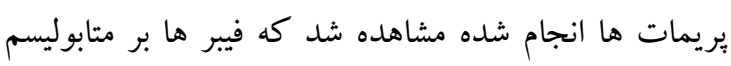

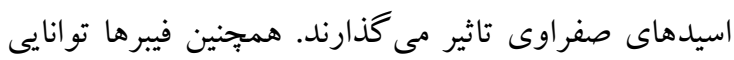




$$
\begin{aligned}
& \text { تشكر و قدردانى } \\
& \text { بدين وسيله از مديريت و يرسنل مركز نخههدارى و يرورش }
\end{aligned}
$$

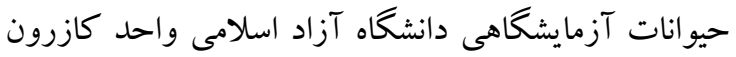

$$
\begin{aligned}
& \text { كه در انجام اين بزُوهش ما را يارى نمودند صميمانه تشكر و واهي }
\end{aligned}
$$

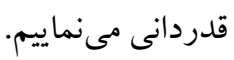

$$
\begin{aligned}
& \text { ديخرنتايج بدست آمده از اين تحقيق مى توان به كاهش }
\end{aligned}
$$

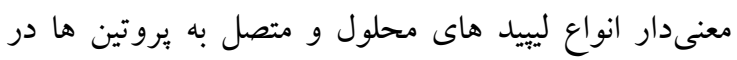

$$
\begin{aligned}
& \text { گرووه سالم تيمار با عصاره نسبت به گروه شاهد سالم نام برد }
\end{aligned}
$$

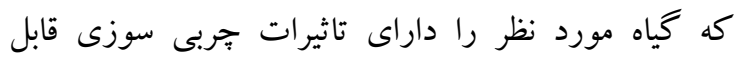

$$
\begin{aligned}
& \text { بررسى معرفى مى كند. }
\end{aligned}
$$

\section{References:}

1. BeladiMousavi SS, Layegh P, Zeraati P, Tamadon MR. Treatment of hyperglycemia in patients with diabetes. MUMS 2014; 57: 866-73. [In Persian]

2. Franz M. Medical nutrition therapy for diabetes mellitus and hypoglycemia of nondiabetic origin. Philadelphia: WB Saunders 2008; 12: 764-8.

3. Andrade-Cetto A, Becerra J. Alfa glucosidase - inhibiting activity of some Mexican plants used in the treatment of type2 diabetes. Diabetes J Ethopharmaco 2008;116:27-32.

4. Bercu R, Dana Jianu L. Anatomy of the Endangered Plant Glaucium Flavum Cr., Occurring on the Romanian Black Sea Littoral. Nature Conservation 2006: 273-80.

5. Majd A, Mehrabian S, Khanafari A. Evaluating antimicrobial effect of Glaucium on Oral microflora. JDM 1996;9:57-66. [In persian]

6. Bogdanov MG, Svinyarov I, Keremedchieva R, Sidjimov A. Ionic liquid-supported solidliquid extraction of bioactive alkaloids. I. New HPLC method for quantitative determination of glaucine in Glaucium flavum Cr. (Papaveraceae). Separ Purif Tech 2012;97:221-7.

7. García-Lafuente A, Guillamón E, Villares A, Rostagno MA, Martínez JA. Flavonoids as anti-inflammatory agents: implications in cancer and cardiovascular disease. Inflam Res 2009; 58:537-52.

8. Spasova M, Philipov S, Nikolaeva-Glomb L, Galabov A, Milkova T. Cinnamoyl-and hydroxycinnamoyl amides of glaucine and their antioxidative and antiviral activities. Bioorg Med Chem 2008;16:7457-61.

9. Bournine L, Bensalem S, Peixoto P, Gonzalez A, Maiza-Benabdesselam F, Bedjou F, et al. Revealing the anti-tumoral effect of Algerian Glaucium flavum roots against human cancer cells. Phytomed 2013;20:1211-18.

10. Cabo J, Cabo P, Jimenez J, Zarzuelo A. Glaucium flavum Crantz. Part v: Hypoglycemic activity of the aqueous extract. Phyto Res 1988;2:198-200.

11. Germano M, D'Angelo V, Sanogo R, Morabito A, Pergolizzi S, De Pasquale R. Hepatorotective activity of Trichilia roka on carbon tetrachloride- induced liver damage in rats. J Pharm Pharmaco 2001;53:1561-74.

12. Kusunoki J, Aragane K, Kitamine T, Kozono H, Kano K, Fujinami K, et al. Ostparandial hyperlipidemia in streptozotocin induced diabetic rats is due to abnormal increase in intestinal acyl coenzyme a: cholesterol acytransferase activity. Arterioscler Thromb Vasc Biol 2000; 20:171-8.

13. Friedewald WT, levy RI, Fredrickson DS. Estimation of the concentration of low density lipoprotein cholesterol in plasma, without use of the preparative ultracentrifuge. Clin Chem 1972;18:499-502.

14. Azizi A, Hatami H, Janghorbani M. Epidemiology of common diseases in Iran. Endocr Res Cen 2001;1379:32-55. 
15. Suji G, Sivakami S. Approaches to the treatement of diabetes mellitus: an overview. Cel Mol Bio 2003;49:635-39.

16. Bar-on H, Roheim PS, Eder HA. Hyperlipoproteinemia in streptozotocin-treated rats. Am Diabetes Assoc 1976;25:500-15.

17. Trombo P, Yates A, Schlicker-Renfo S, Suitor C. Dietary reference intakes: revised nutritional equivalents for folate, vitamin $\mathrm{E}$ and provitamin A carotenoids. J Food Compos Analy 2003;16:379-82.

18. Sabin S, Cavanagh-Kyros J, Barrett T, Jung DY, Ko HJ, Ong H, et al. Molecular target structures in alloxan-induced diabetes in mice. Life Sci 2001:71:1981-94.

19. Schweingruber F, Börner A, Schulze DE. Atlas of stem anatomy in herbs, shrubs and trees. $2^{\text {nd }}$ ed. Jena: Springer, 2011:365.

20. Kiger A, Robert W. Glaucium In Flora of North America. $3^{\text {rd }}$ ed. Oxford; Oxford Uni Press, 1997:283.

21. Bogdanov M, Svinyarov I, Keremedchieva R, Sidjimov A. Ionic liquid-supported solidliquid extraction of bioactive alkaloids. I. New HPLC method for quantitative determination of glaucine in Glaucium flavum Cr. (Papaveraceae). Separ Puri Tech 2012;97:221-7.

22. William DR, James P, Evans IE. Dietary fiber supplementation of a normal breakfast administered to diabetics. Diabeto 1980;18:379-83.

23. Tsai AC, Peng B. Effects of locust bean gum on glucose tolerance, sugar digestion, and gastric motility in rats. J Nutr 1981;111:2152-6.

24. Cortijo J, Villagrasa V, Pons R, Berto L, Martí-Cabrera M, Martinez-Losa, M, et al. Bronchodilator and anti-inflammatory activities of glaucine: In vitro studies in human airway smooth muscle and polymorphonuclear leukocytes. Brt J of Pharmaco 1999;127:1641-51.

25. Lapa G, Sheichenko OP, Serezhechkin AG, Tolkachev ON. HPLC Determination of Glaucine in Yellow Horn Poppy Grass (Glaucium flavum Crantz). Pharmaceut Chem J 2004; 38:441-2.

26. Mowla A, Alauddin M, Rahman MA, Ahmed K. Antihyperglycemic effect of Trigonella foenum-graecum (Fenugreek) seed extract in Alloxan-induced diabetic rats and its use in diabetes mellitus: a brief qualitative phytochemical and acute toxicity test on the extract. Afr J Trad Cam 2009; 6:225-61.

27. Mattson FH, Grundy SM. Comparison of effects of dietary saturated, monounsaturated, and polyunsaturated fatty acids on plasma lipids and lipoproteins in man. J lipid Res 1985; 26: 194-202.

28. Kritchevsky D. Dietary fiber and disease. Bull N Y Acad Med 1982;58:230-41.

29. Kong W, Wei J, Abidi P, Lin M, Inaba S, Wang Y, et al. Berberine is a novel cholesterollowering drugworking through a uniquemechanismdistinct fromstatins. Nat Med 2004;10: 1344-51.

30. Zhang Y, Li X, Zou D. Treatment of Type 2 Diabetes and Dyslipidemia with the Natural Plant Alkaloid Berberine. J of Clin Endocrin Metab 2008;93:2556-65. 